https://doi.org/10.15407/scine17.01.054

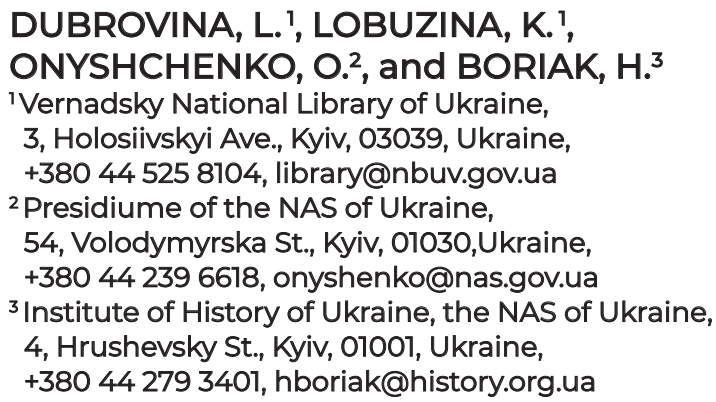

\title{
DIGITAL HUMANITARIAN PROJECT AS A COMPONENT OF DIGITAL HUMANITIES
}

Introduction. Digitalization and innovative sphere of scholarly research, "digital humanities", integrates the methodological apparatus and develops the potential of the humanities and engineering sciences under the condition of their effective interaction. One of the elements of the infrastructure of the digital humanities is research projects to create resources and databases of humanities knowledge.

Problem Statement. Defining the concept of digital humanitarian project and its features is important for the development of interdisciplinary methodology of humanities and information technology.

Purpose. The purpose is to substantiate the properties of Digital Humanitarian Project (DHP) as innovative research product, which is important in modern scientific communication and should be an officially recognized type of scholarly research electronic publication.

Materials and Methods. Methods for historiographical and structural analysis and synthesis of DHP research concepts and completion of humanitarian digital projects at the NAS of Ukraine, and several other methods have been used.

Results. For the first time the research has summarized the concept of DHP as interdisciplinary research product based on the analysis of modern concepts of digital humanities.

Conclusions. The digital humanitarian project as a component of the digital humanities is an innovative research result and a type of scholarly research publication. The specific criteria are as follows: intellectual and innovative contribution of the interdisciplinary team to the development of scientific knowledge; importance for the development of educational and research infrastructure; influence on other DHP. The new model of scientific communication provides for the introduction and improvement of digital technologies in the processes of research and procedures for obtaining, processing, publishing, managing, and using scientific data, forming relevant humanities knowledge bases using achievements of socio-humanities, library and information activities etc. The criterion of new knowledge is not only a new content, but also new means of organization, classification, and interaction with this content.

Keywords: digital humanitarian project, digital humanities.

Citation: Dubrovina, L., Lobuzina, K., Onyshchenko, O., and Boriak, H. Digital Humanitarian Project as a Component of Digital Humanities. Sci. innov. 2021. V. 17, no. 1. P. 54-63. https://doi.org/10.15407/scine17.01.054 
In the network communications of the digital society, there has been emerging a new electronic publishing reality that exists in the structure of a new direction of "digital humanities". The "digital humanities" is a common term for R\&D related to two major areas of research: the humanitarian informatics dealing with the use of computer technology by humanities professionals and the study of the humanitarian consequences of the digital revolution. The main result of research in the field of digital humanities is a digital humanitarian project.

The first stages of the development of digital humanities were related to humanitarian informatics projects, and in our opinion, belong to Joyce Duncan Folk, editor-in-chief of Historical Papers of America, American Bibliographical Center CLIO. As early as 1982, he noted that the electronic revolution had significantly influenced the preparation and role of scholarly research publications (abstracts, indexes, bibliographies, reviews, and reference books) that acquired a new quality and become the object of databases with significant prospects for recognition as unconventional scholarly research publication [2]. Since then, a rather long path towards consensus between the humanities and computer tools and innovative electronic products has been traveled, but researchers continue to believe that monograph remains the "gold standard" of academic humanities research [3].

In the West, where the digital humanities are well developed, researchers have been studying the problem of scientific digitization for many years, conducting special research on the organization of activities, infrastructure, methods, and summarizing the results of these efforts. According to Abby Rumsey (2011), the infrastructure of digitization of socio-humanitarian research involves: - Interdisciplinary research teams capable of mastering new digital forms of work;

- Publishers who are able to support these innovative communities and focus on attracting the attention of a wide audience to digital communications;
- Libraries that can support the use of sources in all formats and ensure the integrity and longterm availability of scientific data;

- Administrators who support result-oriented digital transformations and create conditions for the implementation of digital projects and rewards for them;

- Financial sources that support the innovation of new digital forms of research [4].

The concept of DHP was formed in the course of implementation of the tasks for the humanities (the so-called digital scholarships), which required justification for project funding. A digital project is a project that uses digital methods and computer technology as an integral part of research methodology and infrastructure, dissemination of research results, and engagement of a wide audience of users. Most often, DHPs use methods of analysis and research of digital data, digital publishing, management of digital resources, etc. [5, 6].

The application of both digital and non-digital methods specific to the humanities and quite thorough preparation of humanitarian content are typical for DHP. Digital methods allow researchers to solve problems that are difficult to address using non-digital methods, because of the volume or complexity of the source material. They also make it possible to attract and to introduce into public circulation the research results. An important feature is that the digital methods are not always quantitative (for instance, building of a structure or thematic resource of a particular field of knowledge, electronic publication (publication, website, database) or digitization of historical and cultural heritage sites with appropriate scientific processing of content [7]). The results of DHP fit harmoniously into the modern concept of Service-Oriented Science that has been discussed in detail by Ian Foster, a mathematician at the Argonne National Laboratory, the Department of Computer Science, the University of Chicago (USA). In 2005, he noted that service-oriented science involved transformations in R\&D activities, mainly in scholarly research products that may include, among others, web services, web por- 
tals, databases, and metacatalogues [8]. Information tools, available as services, which are used by researchers realize new opportunities for scholarly research.

The analysis of digital humanities research has demonstrated a significant applied effect and a variety of aspects of the implementation of DHP results, in particular:

- Databases of scholarly research reference information (bibliographic, archival, museum, reference, factual, etc.); audiovisual databases (audio, music, images and video);

- Digital archives of movable and immovable cultural heritage, archives of newspapers, magazines and book library collections;

- Electronic publication of documents and monuments of manuscript and book heritage, including manuscripts, old prints and rare editions, historical documents and narrative sources, letters, genealogical data;

- Comprehensive research on various issues based on electronic questionnaires, interviews, analysis of social media materials;

- Ethnographic, linguistic, sociological, cartographic research for textual or discourse analysis and visualization of any humanitarian data, graphics, diagrams, etc.;

- Data coding and development of metadata structure for building a knowledge base and ontology of the humanities;

- Immersive technologies (3D-virtual reconstruction, augmented and virtual reality, etc.);

- Web applications, mobile applications, websites, virtual exhibitions, online research resources, historical and excursion geoinformation resources, etc. $[9,10]$.

A special feature that distinguishes the digital humanities project from the usual online database, electronic catalog, website or mobile application is the presence of a scientific concept developed for it information architecture and data structure; intended use for the audience on which the research result is focused; expert analysis, scientific description, and evaluation of submitted materials.
The difference between structured and unstructured data is the presence of an additional (secondary) level of formalization and interpretation of data, which creates the conditions for effective use, analysis, and visualization of the information provided. Unstructured data usually refer to arrays of text, images, audio files, or other digital data that do not have a secondary structure superimposed on them.

The experience of the authors and other researchers has shown that important components of the information architecture of a successful DHP are the development of a system of knowledge organization (classification, ontology) and metadata system of historical, cultural or linguistic objects, as well as a conceptual model containing a formalized description of the subject area, which is made without a rigid focus on software. The next stage in the development of DHP is the development of a structure of the knowledge base, namely the translation of the knowledge of an expert in a particular subject area into a computer-readable language. Sometimes, such a process is rather complex, especially in the field of sociohumanitarian research, where there is a lot of implicit and poorly formalized knowledge [11, 12].

As a rule, DHPs are implemented in the web environment in the form of multimedia publications containing multimedia sources (animated and static images, audio and cartographic materials, texts and manuscripts) accompanied with information-analytical tools (geoinformation systems, information retrieval systems, infographics and data visualization tools). This type of multimedia publications includes digital museums and archives, online directories, encyclopedias (digital reference resources that can be considered scholarly research DHP only under the conditions of expert examination and formation of materials by researchers in a particular field of knowledge), and online bibliography with an electronic research infrastructure. Along with digital analogs (surrogates) of digital objects of historical and cultural heritage, new digital publishing platforms create an opportunity to place scientific interpre- 
tations, explanations, and comments, which gives users access to the scientific context. In this way, knowledge and data, research and its objects are productively combined. Each publication format is based on conventional forms of humanities research. However, digital technologies have profoundly affected researchers' relationships with libraries, publishers, and user audiences. The old relations between researcher, editor, and publisher, which were previously separated, are being replaced by collaboration between researchers and IT departments and users, where libraries have an important role to play in integrating the process of creating and disseminating scholarly research information. The publishing model of scientific academies of 19th century (scholarly research article and monograph distributed by a small group of specialists and libraries) is being replaced by web publication of research materials of various types in various formats. These new forms of scholarly research products significantly expand access to information [13].

It is necessary to provide a solution to a wide range of non-trivial tasks: integration of dissimilar multimedia sources into a single digital infrastructure (harmonization of standards for their description and structure of metadata, information and content links); normalization of approaches to the authorship of the resource and the practice of quoting such interactive media, promoting the fair use of their materials; organization of space for cooperation of different specialists within the framework of a joint digital project, expert evaluation and review of materials; mastering of new editorial design tools and "spatial thinking"; development of new methods of evaluation of a multimedia scientific product.

The projects require the integration of the efforts of many highly qualified specialists in various specializations; the development of digital platforms, tools, and methods; and the interdisciplinary opinion of researchers. According to D.M. Berry (2017), such projects are referred to as the "great humanities" in the context of the transition from individual researcher to research teams and big data combined with computational tools. It is a rapidly growing field of research and development, which is formed at the interface of computer technology, humanities, arts, culture, social communications, vocational education, library and information activities.

According to researchers, in the course of implementation of joint DHP, the nature of interdisciplinary cooperation that evolves from instrumental interdisciplinarity (integration of information, data, methods, and tools) to interdisciplinary methodological (comprehensive synthesis of ideas associated with the development of new common conceptual provisions theories within problem-oriented research) changes. At the heart of interdisciplinary approaches there is the organization of scientific cooperation that is always a compromise between autonomy and synergy. Today, in global digital scientific communications, cooperation between disciplines, organizations, countries and coordination of political views necessary to create new knowledge, to solve complex problems, to improve methods and practices, to develop new services and products, and to organize a system of lifelong learning.

According to J. Klein, in many cases, such cooperation requires a revision of the requirements for the organization of intellectual activity, namely, it is necessary to meet such principles as, in particular, integrity (recognizing the contribution of other authors); purposefulness (understanding the importance of their work to achieve a common result); tolerance (understanding that knowledge is always partial and incomplete and may be disseminated and revised); flexibility (the ability to change their point of view based on the knowledge of others); integration (responsible participation that helps to attract the best ideas of each to carry out common tasks) [14].

Scientific and organizational experience of researchers A.H. Poole and D.A. Garwood (2018) has shown that the organization of interdisciplinary teams in a virtual environment is complicated by various unforeseen obstacles, the complexity of translation into different languages, the 
presence of mediators (short-time employees, graduate students, volunteers), division of labor and delegation of responsibilities, the need to resolve conflicts and to clarify technological differences, the distribution of results and authorship in publications, ongoing support for the sustainability and infrastructure of the project, etc. [15]. However, if these barriers are removed, the result is far beyond what individual researchers could achieve. According to the Oxford Handbook of Interdisciplinary Research, DHPs are becoming a driving force contributing to systemic and even fundamental conceptual transformations in many scientific disciplines: new fields of knowledge are being developed based on new computational tools, and their understanding of social impact is getting wider [16].

Another special feature of digital projects is their constant development. As Abby Rumse states it (2011), they are process, not product. In a critical review of DHP, Michael Ullyot formulates this view based on the specifics of scholarly research publications that in accordance with the "planned aging" model, today are tending towards a more dynamic, extensible form that creates conditions for scientific resources to change over time, constantly embracing new knowledge, but needs support and expansion of existing resources [17].

The preparation of materials, evaluation, registration, dissemination, archiving, constant availability and development remain important organizational issues. Unlike the paper edition, the DHP needs constant support in the future, even in the absence of its modification and development. In this context, the key concept is the stability of the DHP in various aspects: a stable and integrated model of metadata management, sustainable support of research needs, stable technical performance, clarity and accessibility for users [18]. As Frodeman R. concludes in the Oxford Handbook of Interdisciplinarity (2017), many complex issues arise at the stage of determining the significance of various aspects of DHP: distinguishing between individual contributions to an in- terdisciplinary team, hierarchy of achievement values, evaluation of innovations that have no counterparts, etc. Researchers note that interdisciplinary and digital research projects cannot be evaluated according to a universal model like other publications, in particular, only from the standpoint of quantity. Instead of such universal approaches, J. Klein (2014) offers expert qualitative evaluation principles for interdisciplinary projects: achieving goals, finding methodological pluralism and epistemological differences, solving cognitive, social, and contextual aspects of cooperation, emergence of innovative unpredictable results, and social contribution.

Generalized guidelines for determining the criteria for peer review of digital projects are offered by Todd Presner (2012), Head of the Digital Humanities Research Program at the University of California, Los Angeles (USA), and can be summarized as follows:

1) The project shall be evaluated as a whole in the environment for which it is developed;

2) The author's contribution of the team members shall be clearly defined at each stage of the project (author of the concept, author of technology and information architecture, author of the content, author of design and presentation solutions, etc.);

3) The intellectual contribution: new knowledge, new methodology, new ways of organizing knowledge and interaction with the content: classification, database structure, design, and interface shall be clearly formulated;

4) Contribution to teaching and research infrastructure: expanding teaching opportunities, influencing the audience of users, promoting the rethinking of complex R\&D problems;

5) Social impact both on the academic community and the general public, which can be measured by methods for analysis of the number of site visitors, citations in conventional and Internet publications, resonance in social media;

6) Expert evaluation (peer review) by researchers of relevant fields (humanities and social sciences, arts, computer science, library science), 
which can determine the project role in the general intellectual landscape;

7) Such factors as the quality and quantity of research, time and intellectual inputs of creators, range, depth, content, ways of content presentation, etc. shall be taken into consideration;

8) Cycles of development, stability, and value: DHPs may evolve through different stages of development, as they grow, change, and improve;

9) It is also necessary to assess the weight of the project and to ensure the storage and access to digital data, etc.

At the present stage, in Ukraine, scientific and educational institutions, research libraries, and information centers implement many DHPs: information portals, digital libraries and archives, institutional repositories, electronic online directories and catalogs, multimedia scholarly research and educational publications, virtual exhibitions and digital collections, and visual cartographic services.

Institutes of the National Academy of Sciences of Ukraine, with the Vernadsky National Library of Ukraine (VNLU) involved, have developed and formed national corporate DHPs: Ukrainica Naukova abstract database [19], Scholarly Research Periodicals of Ukraine national repository [20], Science of Ukraine: Access to Knowledge information portal [21], electronic Encyclopedia of the History of Ukraine [22], integrated electronic library of history [23], Mykhailo Hrushersky Digital Archives (hrushevsky.nbuv.gov.ua), which have become significant infrastructural components of the digital scholarly research and educational space of Ukraine. Digital resources of historical and cultural heritage of Ukraine, documentary archives, manuscript and book heritage [24] also constitute a significant segment.v Among such projects there are Book Monuments of Ukraine, CODE: Manuscripts, Historical and Cultural Collections, Digital Library of Historical and Cultural Heritage, and Ukrainika e-library, which accumulate, integrate, and preserve the national memory of Ukraine in digital format [25].

The website of the Institute of History of Ukraine of the NAS of Ukraine (IHU) has been crea- ted in close cooperation between humanitarian and IT specialists. It is a historical information portal containing interconnected scholarly research data: electronic encyclopedia of Ukrainian history, electronic library and bibliographic information on historical subjects, Internet navigator (bibliography) for historians. The information architecture of the site is based on the concept of related scientific data, in particular the author(s) and the author publications available on the portal; places of publication, publishing house, responsible institution; encyclopedic articles (personalities, organizations, institutions, events, geographical objects, dates, etc.) and research projects related to the subject of research; series, volumes of multi-volume editions, reprints, digitized primary sources, collections of documents; visual, cartographic materials; video, audio materials. The Semantic Web technologies have effectively integrated external information sources (including the VNL information portal), Google search and linguistic technologies into the site materials, created conditions for the historical portal to be "seen" by Internet search engines, and took into account digital science standards to effectively include research results of Ukrainian historians to international scholarly research communications. The models of research metadata, including the formation of personal pages of researchers and repository of publications of IHU staff as well as support of scientific identifiers of authors and publications (ORCID, DOI) have been implemented; the publications and their metadata have been indexed in scientometric system Google Scholar, etc. (history.org.ua).

Also, the DHPs of the institutes of the NAS of Ukraine related to the study of the Holodomor of 1932-1933 should be presented. The Holodomor Digital Archives project of the Institute of History of Ukraine, which was initiated in 2020 aims at forming electronic bank of documents, evidences, scholarly research publications and tools for chronological, geographical, institutional, and personal analysis of information sources (holodomorera.history.org.ua). 
While implementing the Digital Atlas of Ukraine (digital map project of the Ukrainian Research Institute of Harvard University in collaboration with various academic institutions in Ukraine), the Ptukha Institute of Demography and Social Research developed their own methodology for estimating the amount of victims among Ukraine's population caused by the Holodomor and conducted a demographic survey (gis.huri.harvard.edu/historical-atlas/the-greatfamine/) [26].

Encyclopedia of Modern Ukraine (EMU) project has been implemented by the Institute of Encyclopedic Research of the NAS of Ukraine. A methodology for selecting and preparing articles has been developed to promote the generalization and systematization of knowledge about Ukraine, its intellectual and cultural potential, and self-representation in the modern global information space. A large block of articles in the EMU the vast majority of which were prepared by leading experts of the institutes of the NAS of Ukraine and educational institutions deals with scientific areas and concepts (esu.com.ua) [27].

The online resource of the digital library of the Ukrainian Language and Information Fund that is an integral part of the Ukrainian Linguistic Corps and operates in close cooperation with the Potebnia Institute of Linguistics and other research and educational institutions has sparked a massive outcry. The Fund has created a unique electronic resource for many dictionaries of the Ukrainian language, including the fundamental academic explanatory Dictionary of the Ukrainian language in 20 volumes (lcorp.ulif.org.ua) [28].

The authors' efforts towards the implementation of such projects have allowed identifying the characteristics of the organization of activities and content of the project as a product of new scientific quality through a combination of methodologies of socio-humanitarian and information technology research. This primarily includes as follows: - Introducing new forms of organization of research activities, which ensures effective interaction and delegation of powers in research teams, takes into account the author's intellectual contribution of each project member;

- Amending the digital objects with scientific context (interpretations, explanations, comments, etc.), which significantly affects the novelty of information;

- Ensuring the integrity and scientific significance of the elements of research infrastructure as a source of historical, cultural, and social memory, scientific information, multimedia form of scholarly research publication that naturally combines sources and new knowledge;

- Determining the status of completeness or progress, integration ability of the project, which is constantly updated with new information that is accumulated, improves, and requires sustainable measures to manage digital data (storage, update of the platform, access);

- Regarding the role of research libraries as partners who have sources of information, many years of experience in document management technologies, have mastered a set of new IT competencies, knowledge of methods and technologies of digital humanities.

Unfortunately, in the existing models of evaluation of $R \& D$ results, still there is no concept of research DHP as a separate result of research work and electronic publication.

Hence, the digital humanities project as a component of the digital humanities is an independent scientific result of research work and a kind of scholarly research electronic publication. It is possible to define specific criteria of its expert evaluation: intellectual contribution of interdisciplinary team into the development of scientific knowledge; importance for the development of educational and research infrastructure; social impact that can be measured by online visits to the resource and citations in digital social media; author's contribution of each team member; analysis of citations of project materials in scholarly research publications, etc. The new model of scientific communication provides for the introduction and improvement of digital technologies in the processes of scientific research and procedures for obtai- 
ning, processing, publishing, managing, and using scientific data, forming relevant humanities knowledge bases with the use of advanced computer technologies, achievements of socio-humanities, library and information activities etc. The crite- rion of new knowledge is not only new content, but also new means of organization, classification, and interaction with this content. This encourages the development of innovative research and ensures the integration of digital scientific resources.

\section{REFERENCES}

1. Dacos, M. (2011). Manifeste des Digital humanities. ThatCamp Paris. URL: http://tcp.hypotheses.org/501 (Last accessed: 25.06.2020).

2. Falk, J. D. (1982). The Historian Enters the Electronic Age: Bibliographical and Database Publishing. The Public Historian, 4( 2), 35-42. doi: https://doi.org/10.2307/3377354.

3. Berry, D. M., Fagerjord, A. (2017). Digital humanities: Knowledge and critique in a digital age. Cambridge: Polity Books. doi: https://doi.org/10.1515/commun-2020-2083.

4. Rumsey, A. (2011). New-Model Scholarly Communication: Road Map for Change. Scholarly Communication Institute. University of Virginia Library. URL: http://www.uvasci.org/institutes-2003-2011/SCI-9-Road-Map-for-Change.pdf (Last accessed: 24.06.2020).

5. Burdick, A., Drucker, J., Lunenfeld, P., Presner, T., Schnap, J. (2012). A short guide to the digital_humanities. Digital_ Humanities. MIT Press, 121-135. URL: http://arteca.mit.edu/book/digital_humanities (Last accessed: 21.06.2020).

6. What is a digital humanities project? Digital Humanities Institute. The University of Sheffield. URL: https://www.dhi. ac.uk/what-is-a-digital-humanities-project/ (Last accessed: 19.06.2020).

7. Dubrovina, L. A., Lobuzina, K. V., Onyshchenko, O. S., Boriak, H. V. (2020). Digital humanities and databases of documentary cultural heritage in libraries of Ukraine. Manuscript and book heritage of Ukraine, 25, 290-309 [in Ukrainian]. doi: https://doi.org/10.15407/rksu.25.290.

8. Foster, I. (2005). Service-oriented science. Science, 308(5723), 814-817.

9. Drucker, J., Kim, D., Salehian, I., Bushong, A. (2014). Introduction to Digital Humanities Course Book: Concepts, Methods, and Tutorials for Students and Instructors. URL: http://dh101.humanities.ucla.edu/wp-content/uploads/2014/ 09/IntroductionToDigitalHumanities_Textbook.pdf (Last accessed: 20.06.2020).

10. Presner, T. (2012). How to Evaluate Digital Scholarship. Journal of Digital Humanities, 1(4), 36-39. URL: http://journalofdigitalhumanities.org/1-4/how-to-evaluate-digital-scholarship-by-todd-presner/ (Last accessed: 28.06.2020).

11. Lobuzina, K. (2015). Problem-oriented library knowledge bases as a source base social and humanitarian research. Special Historical Subjects, 25, 115-122 [in Ukrainian]. URL: http://nbuv.gov.ua/UJRN/sidptm_2015_25_10 (Last accessed: 21.09.2020).

12. Osuga, S. (1989). Processing of knowledge. Moscow: Mir [in Russian].

13. Gardiner, E., Musto, R. (2015). Digital Environments. The Digital Humanities. Cambridge: Cambridge University Press , 82-96. doi: https://doi.org/10.1017/CBO9781139003865

14. Klein, J. (2014). Interdisciplining Digital Humanities: Boundary Work in an Emerging Field. Ann Arbor, MI: University of Michigan Press. URL: https://www.press.umich.edu/2525468/interdisciplining_digital_humanities (Last accessed: 22.09.2020).

15. Poole, A., Garwood, D. (2018). Interdisciplinary scholarly collaboration in data-intensive, public-funded, international digital humanities project work. Library \& Information Science Research, 40(3-4), 184-193. doi: https://doi.org/ 10.1016/j.lisr.2018.08.003.

16. Frodeman, R. (Ed.) (2017). The Oxford Handbook of Interdisciplinarity. Oxford Handbooks Online. URL: https://doi. org/10.1093/oxfordhb/9780198733522.001.0001.

17. Ullyot M. (2013). Review Essay: Digital Humanities Projects. Renaissance Quarterly, 66(3), 937-947. doi: https://doi. org/10.1086/673587.

18. Edmond, J., Morselli, F. (2020). Sustainability of digital humanities projects as a publication and documentation challenge. Journal of Documentation. URL: https://doi.org/10.1108/JD-12-2019-0232.

19. Petrov, V. V., Onyshchenko, O. S., Kriuchyn, A. A., Lobuzina, K. V., Minina, N. M., Zaichenko, N. Ya. (2015). The development of national referencing system: To the 20th anniversary of the Ukrainian abstract journal «Dzherelo». Visnyk of the National Academy of Sciences of Ukraine, 10, 71-74 [in Ukrainian].

20. Lobuzina, K. (2015) Open Access Electronic Scientific Periodicals: Semantic Web Technologies for Libraries. Library journal, 3, 18-23 [in Ukrainian]. URL: http://nbuv.gov.ua/UJRN/bv_2015_3_5 (Last accessed: 25.09.2020). 
21. Lobuzina, E. V. (2017). Information portal «Science of Ukraine: access to knowledge». Libraries of national academies of sciences, 14, 35-46 [in Russian]. URL: http://nbuv.gov.ua/UJRN/bnan_2017_14_6 (Last accessed: 25.09.2020).

22. Smolii, V. A., Boriak, H. V. (2015). Modern historical encyclopedistics: achievements and perspectives of development. Visnyk of the National Academy of Sciences of Ukraine, 3, 44-60 [in Ukrainian]. URL: http://resource.history.org.ua/ publ/UIJ_2014_4_3 (Last accessed: 25.09.2020).

23. Boriak, H. (2013). On the question of the state and prospects of development of network information resources of social and humanitarian sciences. Special Historical Subjects, 21, 9-25 [in Ukrainian]/ URL: http://resource.history.org.ua/ publ/sid_2013_21_9 (Last accessed: 25.09.2020).

24. Dobrovolska, V. (2020). Electronic library «Ukrainica» as the unique integrated resource of digital documentary heritage. Library Science. Record Studies. Informology, 1, 79-87 [in Ukrainian]. URL: http://nbuv.gov.ua/UJRN/bdi_2020_1_14 (Last accessed: 28.09.2020).

25. Rudnytskyi, O., Levchuk, N., Volovyna, O., Shevchuk, P., Kovbasiuk, A. (2015). Demography of a Man-Made Human Catastrophe: the Case of Massive Famine in Ukraine 1932-1933. Demography and social economy. Part 1, 2(24), 11-30. Part 2, 3(25), 43-63 [in Ukrainian].

26. Dubrovina, L., Kovalchuk, H. (2016). Development of electronic information resources of manuscript and book heritage in The Vernadsky National Library of Ukraine. Library journal, 1,3-11 [in Ukrainian]. URL: http://nbuv.gov.ua/UJRN/ bv_2016_1_3 (Last accessed: 28.09.2020).

27. Zhelezniak, M. (2009). Encyclopedia of Modern Ukraine: history, current state and prospects. Encyclopedia Herald of Ukraine, 1, 5-13 [in Ukrainian].

28. Ozerova, N. H., Shyrokov, V. A. (2011). The first volume of the Dictionary of the Ukrainian language in 20 volumes. Movoznavstvo, 2, 3-13 [in Ukrainian]. URL: http://nbuv.gov.ua/UJRN/MoZn_2011_2_2 (Last accessed: 28.09.2020).

Received 26.10.20

Revised 23.11.20

Accepted 23.11.20

\author{
Л.А. Дубровіна ${ }^{1}$, К.В. Лобузіна ${ }^{1}$, \\ О.С. Онищенко ${ }^{2}$, Г.В. Боряк ${ }^{3}$ \\ ${ }^{1}$ Національна бібліотека України імені В.І. Вернадського, \\ просп. Голосіївський, 3, Київ, 03039, Україна, \\ +380 44525 8104, library@nbuv.gov.ua \\ 2 Президія НАН України, \\ вул. Володимирська, 54, Київ, 01030, Україна, \\ +380 44239 6618, onyshenko@nas.gov.ua \\ ${ }^{3}$ Інститут історії України НАН України, \\ вул. Грушевського, 4, Київ, 01001, Україна, \\ +380 44279 3401, sekretar@history.org.ua

\section{ЦИФРОВИЙ ГУМАНІТАРНИЙ ПРОЕКТ ЯК СКЛАДОВА ЦИФРОВОЇ ГУМАНІТАРИСТИКИ}

Вступ. Розвиток інноваційної сфери наукових досліджень - «цифрової гуманітаристики» - інтегрує методичний апарат та розвиває потенціал гуманітарних і технічних наук за умови їхньої ефективної взаємодії. Одним з елементів інфраструктури цифрової гуманітаристики є наукові проєкти зі створення ресурсів і баз даних гуманітарного знання.

Проблематика. Визначення поняття цифрового гуманітарного проєкту (ЦГП) та його особливостей є важливим для розвитку міждисциплінарної методології гуманітаристики та інформаційних технологій.

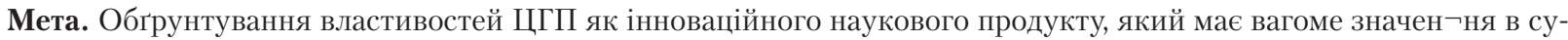
часній науковій комунікації та повинен визначатися як офіційний вид наукової електронної публікації.

Матеріали й методи. Використано історіографічний та структурний аналіз наукових концепцій поняття ЦГП та доробку деяких гуманітарних цифрових проєктів Національної академії наук України, а також низку інших методів.

Результати. Вперше узагальнено поняття ЦГП як міждисциплінарного наукового продукту на основі аналізу концепцій цифрової гуманітаристики. 
Висновки. Цифровий гуманітарний проєкт як складова цифрової гуманітаристики є інноваційним науковим результатом та видом наукової публікації. Специфічними критеріями його є: інтелектуальний та інноваційний внесок міждисциплінарного колективу у розвиток наукового знання; значення для розвитку освітньої та наукової дослідницької інфраструктури; вплив на інші ЦГП. Нова модель наукової комунікації передбачає необхідність введення цифрових технологій у процеси наукового дослідження та процедури отримання, опрацювання, публікації, управління та використання наукових даних, формування актуальних гуманітарних баз знань, досягнень соціогуманітарних наук, бібліотечної та інформаційної діяльності та ін. Критерієм нового знання стає не лише новий контент, а й нові засоби організації, класифікації та взаємодії з цим контентом.

Ключові слова: цифровий гуманітарний проєкт, цифрова гуманітаристика. 